\title{
Javaslat az európai és hazai ajánlásokat követö lipidcsökkentő terápia hatékonyabb megvalósítására a magyarországi gyakorlatban akut koronáriaesemény utáni betegekben
}

\author{
Márk László', Harangi Mariann², Paragh György², Nagy Gergely György³, \\ Kőszegi Zsoltt ${ }^{4}$, Bednárszky lldikó ${ }^{5}$, Járai Zoltán ${ }^{6,7}$, Csanádi Zoltán ${ }^{8}$
}

\author{
1Békés Megyei Központi Kórház, Pándy Kálmán Tagkórház, Kardiológia Osztály, Gyula \\ ²Debreceni Egyetem Általános Orvostudományi Kar, Belgyógyászati Intézet, \\ Anyagcsere Betegségek Nem Önálló Tanszék, Debrecen \\ 33Borsod-Abaúj-Zemplén Megyei Központi Kórház, I. sz. Belgyógyászati Kardiológiai Osztály, Miskolc \\ 4Szabolcs-Szatmár-Bereg Megyei Kórházak Jósa András Egyetemi Oktatókórház, Nyíregyháza \\ ${ }^{5}$ Debreceni Egyetem Általános Orvostudományi Kar, Családorvos Tanszék, Oktató Praxis, Debrecen \\ ${ }^{6}$ Szt. Imre Egyetemi Oktatókórház, Kardiológiai Profil, Budapest \\ ${ }^{7}$ Semmelweis Egyetem, Általános Orvostudományi Kar, Városmajori Szív- és Érgyógyászati Klinika, \\ Érsebészeti és Endovaszkuláris Tanszék, Angiológiai Tanszéki Csoport, Budapest \\ ${ }^{8}$ Debreceni Egyetem Általános Orvostudományi Kar, Kardiológia Intézet, Debrecen
}

Levelezési cím:

Dr. Márk László, Békés Megyei Központi Kórház, Pándy Kálmán Tagkórház, Kardiológia Osztály

5700 Gyula, Semmelweis u. 1. E-mail: dr.mark.laszlo@gmail.com

\begin{abstract}
Újabb klinikai vizsgálatok és metaanalízisek egyértelművé tették, hogy a lipidcsökkentés, ezen belül az LDL-koleszterin-szint befolyásolása, a sikeres primer és szekunder kardiovaszkuláris prevenciós stratégia kulcsa. Mindegy, hogy melyik gyógyszerrel, csak minél korábban elkezdve, minél hosszabb ideig és minél alacsonyabban tudjuk tartani az LDL-koleszterin-értéket, annál nagyobb a várható klinikai haszon. Az is egyértelművé vált, hogy minél nagyobb a kockázat, annál jelentősebb az elkövetkező években elérhető nyereség. Ugyanakkor azt is látnunk kell, hogy az akut koronáriaszindrómán átesett betegeink kellő hatékonyságú lipidcsökkentő kezelésének biztosításában még fontos és sürgető feladataink vannak.

A Magyar Kardiológusok Társasága és a Magyar Atherosclerosis Társaság elnökei és főtitkárai, valamint az ateroszklerotikus érbetegségek által különösen súlyosan érintett négy észak- és kelet-magyarországi megye (Borsod-Abaúj-Zemplén, Szabolcs-Szatmár-Bereg, Hajdú-Bihar és Békés) kardiológiai osztályainak vezetői, továbbá egy családorvosként is dolgozó kardiológus szakorvos közös javaslatot fogalmaztak meg a hatékonyabb lipidcsökkentő kezelés gyakorlati megvalósítására akut koszorúér-esemény után. Ezek legfontosabb elemei: 1.) a betegre szabott teendők pontos megfogalmazása a zárójelentésben; 2.) a családorvosok fokozott bevonása; 3.) a kontrollvizsgálatok idejének megválasztása és tudatosítása; 4.) a laboratóriumi kontroll pontos elöírása; 5.) a betegek részletesebb felvilágosítása, oktatása.

A hosszú távú kardiovaszkuláris morbiditás és mortalitás adatainak javítása érdekében fontos lépés lenne, ha az akut koronáriaszindrómán átesett betegeket kezelö kollégák, köztük a beteget az akut esemény után elbocsájtó kardiológus, a gondozást végző szakorvos és a beteg családorvosa az alábbiakban megfogalmazott gyakorlati szempontok szerint járnának el, azokat rutinszerűen alkalmaznák. Ebbe a tevékenységbe egyre inkább bele kellene vonni erre kiképzett szakdolgozókat, és figyelembe vehető, hogy ez az orvoslásnak olyan területe, amelyben lehet és érdemes kihasználni a telemedicina lehetőségeit is.
\end{abstract}

Kulcsszavak: akut koronáriaszindróma, kardiovaszkuláris prevenció, lipidcsökkentő kezelés, statinok, ezetimib

A szerzők az ajánlást a Magyar Kardiológusok Társasága és a Magyar Atherosclerosis Társaság szakértő tagjaiként készítették.

A kézirat 2021. 08. 05-én érkezett a szerkesztőségbe, 2021. 09. 01-jén került elfogadásra. 


\section{Expert recommendation for a more effective implementation of lipid lowering therapy pursuing the European and Hungarian guidelines in patients after acute coronary syndrome}

The most recent studies and meta-analyses proved that the lipid lowering therapy, the lowering of LDL-cholesterol level has become the key element of the primary and secondary cardiovascular prevention. There is no difference which drug is used, but LDL-cholesterol must be decreased to the lowest achievable level, as soon, as long and as low, as possible. Obviously, it is clear as well, that if the risk is higher, the available benefit is greater. At the same time we have to recognise that in lipid lowering treatment of patients after acute coronary syndrome there is still remaining room and urgent task for improvement.

The presidents and general secretaries of two medical associations, the Hungarian Society of Cardiology and the Hungarian Atherosclerosis Society, and the leaders of cardiology departments of four counties in the North-Eastern part of Hungary (Borsod-Abaúj-Zemplén, Szabolcs-Szatmár-Bereg, Hajdú-Bihar and Békés) and a cardiologist working as a general practitioner too, developed a common action plan to improve the lipid lowering treatment in patients after ACS. Its key elements are: 1.) detailed instructions for patients about next steps on hospital discharge report; 2.) increased involvement of general practitioners; 3.) exact timing and raising awareness of follow-up examinations; 4.) accurate planning of laboratory controls; 5.) the better patient education.

In order to improve long-term cardiovascular morbidity and mortality, it would be important for all colleagues who are is involved in the management of patients with acute coronary syndrome, such as discharging cardiologists, caregiver specialists and general practitioners to routinely apply recommendations listed in this article. In this practice trained nurses could be involved as well, in addition the optimalisation of lipid lowering treatment is a therapeutic area too, where the advantage of telemedicine should be applied.

Keywords: acute coronary syndrome, cardiovascular prevention, lipid lowering therapy, statins, ezetimibe

Az akut koronáriaszindróma (ACS) sürgősségi ellátásának magyarországi hálózata jól müködik, amit az is jelez, hogy ezen diagnózissal intézetbe kerülők kórházi halálozása az irányt mutató európai adatokhoz hasonló, ugyanakkor a későbbiek során „nyílik az olló”, egy évvel az esemény után a mortalitás hazánkban már lényegesen magasabb. Ennek egyik oka lehet az optimális, az ajánlásokat követő életmódi és gyógyszeres terápiás elvek következetes alkalmazásának elmaradása $(1,2)$.

A lipidcsökkentő terápia a kardiovaszkuláris prevenció egyik alapeleme lett. Az ESC/EAS 2019-es évi és a VIII. Magyar Kardiovaszkuláris Konszenzus Konferencia 2020-as ajánlásaiban az igen nagy kockázatú betegek LDL-koleszterin (LDL-C) célértékeit a korábbi $1,8 \mathrm{mmol} / \mathrm{l}$-ről $1,4 \mathrm{mmol} / \mathrm{l}-$ re szállították le, és elöírás a legalább 50\%-os LDL-C-csökkenés. Ha két éven belül ismétlődik az éresemény, akkor $1,0 \mathrm{mmol} / \mathrm{l}$ az elérendő $\operatorname{LDL}-\mathrm{C}(3,4)$.

Bár ACS-en átesett betegek esetén az irányelvekben elöírt célértékek elérésének fokozott jelentősége van (5), jól ismert tény, hogy ez világszerte nem történik megfelelő szinten $(2,6,7)$ (1. ábra). Az Európa 18 országában közel 6 ezer beteg bevonásával végzett $\mathrm{DaVin}$ ci-vizsgálatban (EU-Wide Cross-Sectional Observational Study of Lipid-Modifying Therapy Use in Secondary and Primary Care) ismert érbetegekben az 1,8 $\mathrm{mmol} / \mathrm{l}$ LDL-koleszterin-szintet (LDL-C) 41\%, az 1,4 mmol/l-t $18 \%$ gyakorisággal érték el. A 2. ábra azt mutatja be, hogy a 2659 ismert érbeteg esetében a REACH (Reduction of Atherothrombosis for Continued Health) sco- re szerint mennyi volt az LDL-C alapján számított újabb kardiovaszkuláris esemény 10 éven belüli valószínüsége. A megoszlás alapján látható, hogy a betegek $82 \%$ ának 20\%-nál nagyobb esélye van az éresemény ismétlődésére, és ez a kockázat a betegek 31\%-ánál $40 \%$-nál nagyobb (7). Az adatok azt jelzik, hogy a lipidcsökkentő terápiában még jelentős tartalékok vannak a kardiovaszkuláris kockázat csökkentésére.

Békés megyében történt retrospektív vizsgálatok azt igazolták, hogy 2015-16-ban az ACS miatt PCI-n átesett betegek csupán 73\%-ának, 2017-18-ban pedig alig több mint a felének volt az adatbázisokban fellelhető lipideredménye a beavatkozás utáni évben $(2,6)$. Ez is azt támasztja alá, hogy a szívinfarktust túlélt betegek gondozása nem kellő szervezettséggel és különösen nem egységes elvek szerint történik Magyarországon. Szisztematikus visszahívási rendszer hiányában esetleges a kontrollok időpontja és a gondozást végző kollégák (invazív kardiológus, szakrendelésen dolgozó kardiológus, családorvos, belgyógyász, lipidológus, magánorvos stb.) munkája nem kellöen összehangolt, emiatt sok esetben közöttük elvész a beteg.

A hazai helyzet javítása érdekében az alábbiakban néhány konkrét gyakorlati javaslatot fogalmazunk meg az ACS utáni lipidcsökkentő kezelésre vonatkozóan.

- A 3. ábra az ACS utáni optimális lipidcsökkentő kezelés sémáját mutatja. ACS-ben nagy intenzitású statin indítandó, a fö cél az 1,4 $\mathrm{mmol} / / \mathrm{l}$ és legalább 50\%-os LDL-C-csökkenés. Ezek elérése nem könnyü, nagy intenzitású statinkezeléssel $50 \%$ esély van az $1,4 \mathrm{mmol} / \mathrm{l}$ elérésére, ha ezeti- 


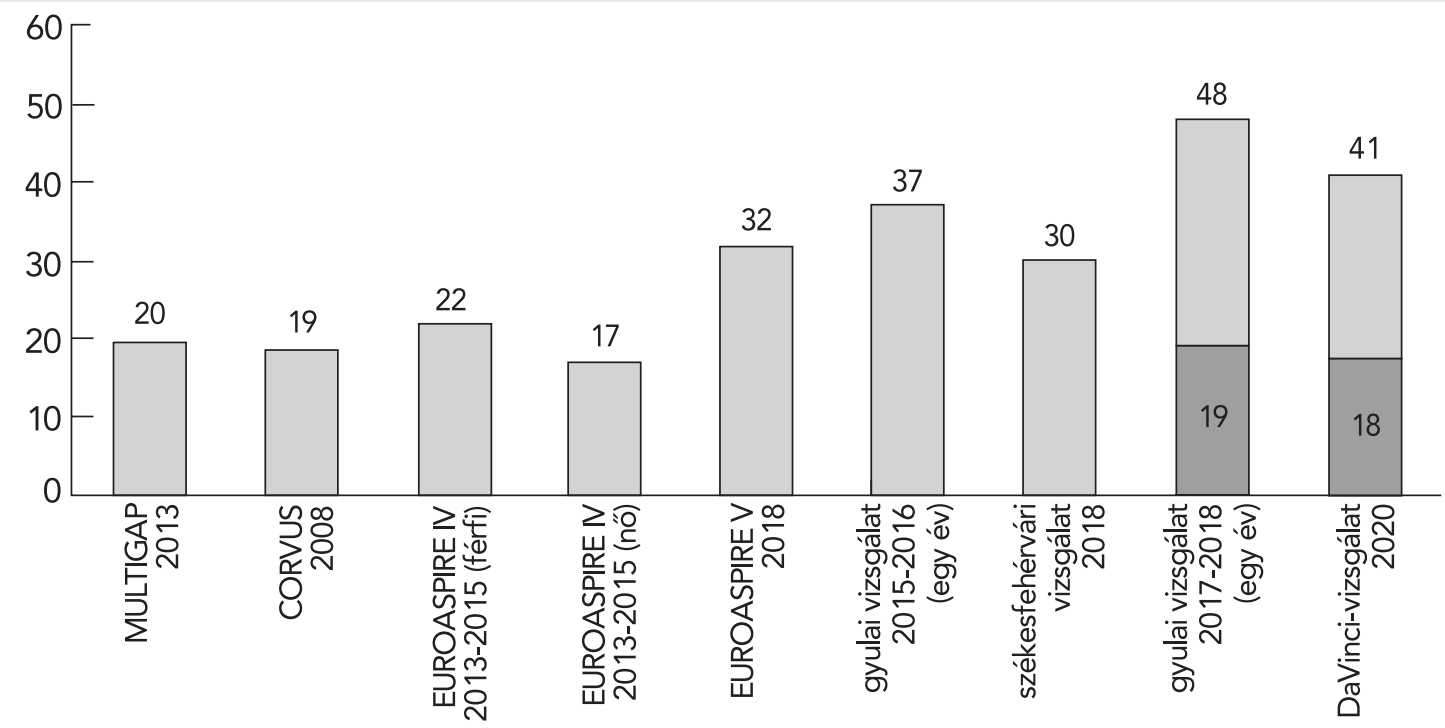

1. ÁBRA. Az 1,8 mmol/I LDL-koleszterin-célértéket elérők aránya (\%) igen nagy kockázatú betegekben magyar és európai adatok alapján, valamint 2018-as székesfehérvári, a 2015-2016-os és a 2017-2018-as gyulai vizsgálatban (az utolsó oszlopokban jelöltük az 1,4 mmol/l elérésének arányát is)

mibet is adunk, akkor ez 66\%-ra nő (8). A betegek hazabocsájtásakor ügyelni kell arra, hogy nagy intenzitású statint (lehetöleg $40 \mathrm{mg}$ rosuvastatint vagy $80 \mathrm{mg}$ atorvastatint) kapjanak.

- A statinok mellett az ezetimibnek nagyobb szerepet kell kapnia! A Nemzeti Szívinfarktus Regiszterbe (NSZR) 2019-ig bevitt betegek 24,8\%-a korábban ACS-en vagy $\mathrm{PCl}-n$ esett át (6). Nagy terápiás elörelépés lenne, ha ezen betegek elbocsátása, amennyiben $1,4 \mathrm{mmol} / \mathrm{l}$ felett volt a bejöveteli LDL-C, nagy intenzitású statin + ezetimib javaslattal történne. (Az NSZR adatai szerint recidív beavatkozáson átesettek 2,6\%-a kapott csak ezetimibet.)
- A statinok adásakor, különösen nagyobb adagok esetén, figyelemmel kell lennünk a beteg esetleges statinintoleranciájára (ez gyakran áthidalható, ha a beteggel türelmesen megbeszéljük, hogy az élethosszabbító, alkalmasint életmentő hatású ACS után), és panasz esetén is törekedni kell a legnagyobb tolerált adag folyamatos szedésének elérésére. Igazolt statinintolerancia, familiáris hypercholesterinaemia, extrém magas LDL-C-szint esetén lipidológiai szakambulancia vagy lipidcsökkentő kezelésben járatos gondozóorvos bevonása mérlegelendő a beteg optimális kezeléséhez.

- Ha nagy intenzitású statin + ezetimib adásával sem értünk el célértéket, mérlegelnünk kell egyedi
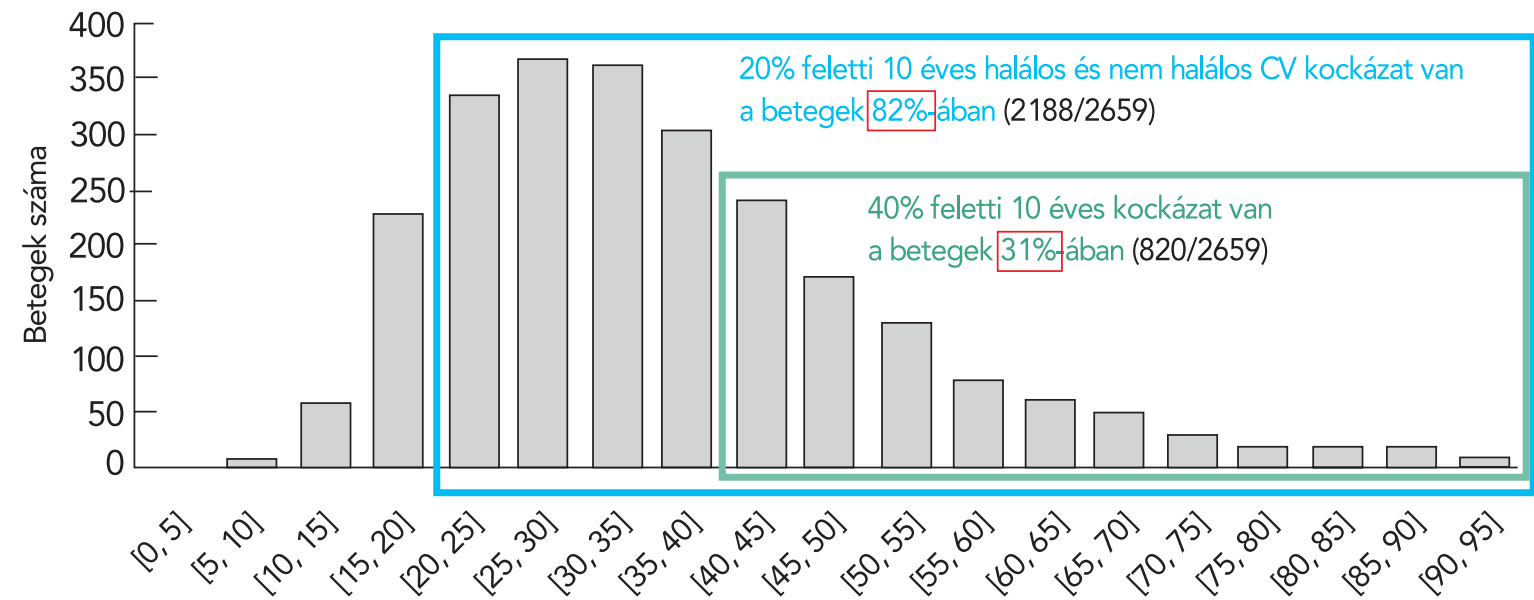

10 éven belüli kardiovaszkuláris esemény kockázata a REACH score alapján

2. ÁBRA. A halálos és nem halálos kardiovaszkuláris események becsült 10 éves LDL-C mérésén alapuló kockázata ateroszklerotikus érbetegségben szenvedőkön (REACH [Reduction of Atherothrombosis for Continued Health] score) a DaVinci-vizsgálat alapján 


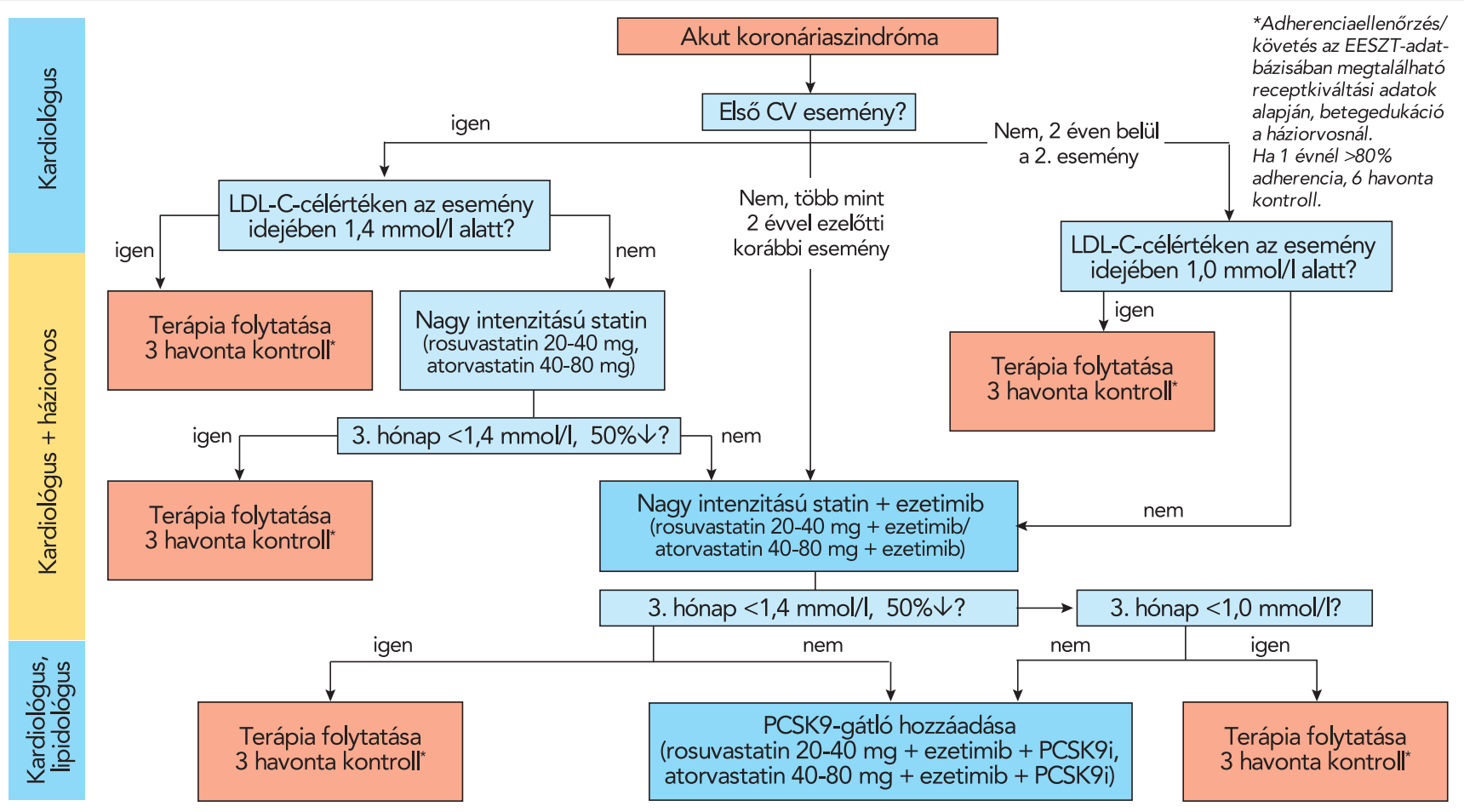

3. ÁBRA. Ajánlás az akut koronáriaszindróma utáni lipidcsökkentő terápia optimalizálására

méltányossági kérelem beadását PCSK9-gátló alkalmazásának engedélyezéséhez.

- A beteg a kórházi kezelése alatt kezébe kapja a mellékletben látható szöveget tartalmazó lapot (Szakorvosi tájékoztató) a kezelőorvos részletes, a betegség természetére, progresszív jellegére és a prognózis javításának lehetőségeire vonatkozó szóbeli felvilágosítása mellett.

- A zárójelentésbe kerüljön be az alábbi szöveg: „A beteg az igen nagy kardiovaszkuláris kockázatú csoportba sorolható, amelynek megfelelően LDL-C-célértéke 1,4 mmol/l, illetve legalább 50\%os LDL-C-csökkentés szükséges.” vagy „A beteg kiemelten nagy kardiovaszkuláris kockázatú, ennek megfelelően LDL-C-célértéke 1,0 mmol/l." és „A célérték elérésének ellenőrzése és az esetleges terápiamódosítás elbírálása céljából 3 hónap elteltével kardiológus szakorvosnál ismételt kontroll javasolt (lehetőség szerint) friss laboratóriumi vizsgálati lelettel (amelyen a lipidvizsgálatnak feltétlen szerepelnie kell, és célszerü kreatin-kináz, vérkép, máj- és vesefunkció ellenőrzés is)". Ily módon a zárójelentésen a családorvost is értesítsük a legközelebbi ellenőrzés tervezett időpontjáról ezáltal már őt is bevonva az utógondozásba. Fontos továbbá, hogy ennek a betegspecifikus utasításnak a pontos betartásáról a beteg is kapjon részletes felvilágosítást.

- Hazabocsájtáskor és lehetőség szerint minden kontroll esetén a beteg kapjon konkrét időpontot a következő vizsgálatra és lássuk el beutalóval lipidvizsgálatra, hogy friss laboreredménnyel jelenhessen meg az ellenőrzésen.

- Ismert, hogy a lezajlott ACS után közvetlenül a betegekben nagyobb a hajlandóság a jobb adherenciára, amit fontos kihasználnunk. A beteg minden ellenőrzéskor részesüljön életmódra és adherenciára vonatkozó tanácsadásban.

- Ha korábban nem volt a betegnek éreseménye, akkor carotis ultrahangvizsgálat és perifériás érbetegség keresése (boka-kar index) indokolt.

- A lipidcsökkentő kezelés monitorozása olyan területe az orvoslásnak, ahol a telemedicinának kiemelt szerepe lehetne. A laboreredmények megbeszélése történhet telefonon vagy videotelefonon is, hiszen a célérték elérésének mikéntjét és lépéseit az orvos ilyen módon is tudja irányítani. A telemedicina alkalmazhatóságát a helyi viszonyok és az adott beteg körülményei befolyásolhatják, ezeket érdemes figyelembe venni.

\section{Ko̊vetkeztetések}

Az irányelveknek megfelelő terápia szélesebb körü alkalmazásával, benne a lipidcélértékek elérésére való nagyobb odafigyeléssel javíthatók lennének az ACS-en átesett hazai betegek életkilátásai, ahogy azt újabb klinikai vizsgálati elemzések is igazolják (10). 
Az irányelvek betartása, a lipidcélértékek elérése nem elméleti, hanem nagyon is gyakorlati feladat, amelynek első lépése lehet a fentiek bevezetése a mindennapi rutinba. Ez minden ACS-en átesett beteget kezelő kolléga kiemelt felelőssége, beleértve az elbocsájtó kardiológust, a gondozást végző szakorvost, vagy a beteg családorvosát. A célértékek és a teendők egyértelmü megfogalmazása ezt nagymértékben támogathatja, ezért időszerü lenne ezen elvek egységes, országos szintü bevezetése, természetesen az adott centrum vagy gondozóhely egyéni lehetőségeinek figyelembevételével.

\section{Nyilatkozat}

A szerzők kijelentik, hogy az összefoglaló közlemény megírásával kapcsolatban nem áll fenn velük szemben pénzügyi vagy egyéb lényeges összeütközés, összeférhetetlenségi ok, amely befolyásolhatja a közleményben bemutatott eredményeket, az abból levont következtetéseket vagy azok értelmezését.

\section{SZAKORVOSI TÁJÉKOZTATÓ \\ akut koszorúér-esemény (szívinfarktus) vagy koszorúér-tágítás miatt gyógykezelt betegek számára a koleszterincsökkentő terápiáról}

\section{Tisztelt Betegünk!}

Önnek a szívizom vérellátását biztosító koszorúerek súlyos szűkülete (elzáródása) miatt létrejövő, életet veszélyeztető tünetegyüttes, az ún. akut koronáriaszindróma, és/vagy szívkatéteres beavatkozással elvégzett koszorúér-tágítás tette szükségessé a gyógykezelését osztályunkon.

Mi az oka a betegség kialakulásának?

Az ok az érelmeszesedés, amely egy évtizedekig tartó, folyamatosan romló folyamat, amelynek eredménye az ütőereket szűkítő, egyre súlyosabb vérellátási zavart okozó, az erek belsejében létrejövő felrakódás (ún. plakk) kialakulása. Hajlamosítanak rá örökletes tényezők, valamint a kockázatot fokozó, a folyamat elörehaladását segítő tényezők, amelyek egy része nem küszöbölhető ki (életkor, nem, genetikai adottságok), míg mások életmódváltással és megfelelő gyógyszeres kezeléssel megváltoztathatók: mint például a dohányzás, cukorbetegség, magas vérnyomás és a magas (célérték feletti) koleszterinszint.

\section{Magas koleszterinszint szerepe az érelmeszesedés}

kialakulásában

A koleszterin a vérzsírok egyik összetevője. Amikor koleszterinröl beszélünk, akkor az összkoleszterint értjük alatta. Vérben mért értéke párhuzamosan változik az úgynevezett rossz, ártalmas koleszterinével, az LDL-koleszterinnel. Az LDL-részecskék mennyisége szorosan összefügg az érelmeszesedés, ezáltal szív- és érrendszeri betegségek kialakulásának kockázatával, ezért csökkentése a további érszűkület és érelzáródás megelőzésének legfontosabb eszköze.

\section{Milyen LDL-koleszterin-szint elérése szükséges az} Ön esetében?

A laborleleteken gyakran jelölik meg az ún. „normálértéket”, vagy „nem kóros” értéket, ami az egészségesnek gondolt népesség felméréseinek adataiból kalkulált szám. Azonban az ismert szív-, és érbetegségben szenvedő betegeknél, ezeknél az értékeknél jóval alacsonyabb „célértékek” kerültek meghatározásra. $\mathrm{Az}$ Ön esetében az egyik elérendő cél az $<1,4$ $\mathrm{mmol} / \mathrm{l}$, bizonyos esetekben $1,0 \mathrm{mmol} / \mathrm{l} \mathrm{LDL-koleszterin-szint.}$ A célérték elérése mellett előirás az LDL-koleszterin legalább $50 \%$-os csökkentése is, amitől - a klinikai vizsgálatok eredményei szerint - a meglévő plakkok megkisebbedése várható.
Hogyan lehet ezt az LDL-koleszterin-célértéket elérni?

Sajnos a koleszterinszegény diéta, az optimális testsúly elérése és megtartása, valamint a rendszeres testmozgás, bár nagyon fontos a szív- és érrendszeri események megelőzése szempontjából, többnyire nem elegendő, ezért gyógyszeres koleszterincsökkentő kezelés szükséges. Ennek első lépése egy, a koleszterin termelését gátló statintípusú szer (atorvastatin vagy rosuvastatin) alkalmazása. Amennyiben ez nem elég, önnek a kezelőorvosa a statin mellett a koleszterin felszívódását gátló ezetimibet tartalmazó kombinált kezelést javasolhat. Indokolt esetekben további hatékony koleszterinszint-csökkentő szerek is felírhatók, amelyek injekciós formában adagolhatók. Ezek a gyógyszerek hatékonyak, biztonságosak, és bizonyítottan, jelentősen csökkentik a szív- és érrendszeri betegségek kialakulásának kockázatát.

Meddig van szükség a koleszterincsökkentö kezelésre? Mivel már kialakult érelmeszesedése van, a további súlyosbodás megelőzése céljából önnek tartósan és folyamatosan alkalmaznia kell a koleszterincsökkentő gyógyszeres kezelést, ennek felfüggesztése esetén a kockázat ismét nőni fog. Nagyon ritkán mellékhatás is elöfordulhat, amennyiben ilyet észlel, azt beszélje meg a kezelőorvosával, de a kezelést csak a vele történt megbeszélés után módosithatja.

Mit nyerhet a hatékony koleszterincsökkentéssel?

A hatékony koleszterincsökkentő kezeléssel elért LDL-koleszterin-célok akár 10-15 évvel meghosszabbíthatják a további koszorúéresemény-mentes életéveinek számát, ezzel jelentősen javíthatják az életkilátásait.

Mi a teendője a továbbiakban?

Önnek, mint éreseményen vagy koszorúér-tágításon átesett betegnek élete végéig tartó kardiológiai gondozáson javasolt részt venni. Eleinte 3 havonta, majd általában félévente hívjuk vissza ellenőrzésre, de ha állapota valami miatt szükségessé teszi, akkor gyakrabban. Az első ellenörzésre - legtöbbször a kardiológiai rehabilitációs kezelés után - azonban néhány hónap múlva kerül sor. A gondozás során kezelőorvosa ellenőrzi az LDL-koleszterin-szintjét, ezért rendszeres laborvizsgálatok elvégzése szükséges. Az ennek alapján javasolt koleszterincsökkentő kezelés hozzájárulhat az ön egészségének megőrzéséhez és életkilátásainak javulásához. 


\section{Irodalom}

1. Jánosi A. Adatok a szívinfarktus miatt kezelt betegek ellátásának helyzetéről. Nemzeti Szívinfarktus Regiszter 2014-2018. Card Hung 2019; 49: 249-254.

https://doi.org/10.26430/CHUNGARICA.2019.49.4.249

2. Dani Gy, Baranyai Cs, Vendrey R, et al. Akut koronáriaszindrómával kezelt betegek lipidcsökkentése és annak tapasztalatai régiónkban. Metabolizmus 2020; 18: 325-331.

3. Mach F, Baigent C, Catapano AL, et al; ESC Scientific Document Group. 2019 ESC/EAS Guidelines for the management of dyslipidaemias: lipid modification to reduce cardiovascular risk. Eur Heart J 2020; 41: 111-188. https://doi.org/10.1093/eurheartj/ehz455

4. A VIII. Magyar Kardiovaszkuláris Konszenzus Konferencia különszám. Metabolizmus 2021; 19: 1-66.

5. Banach M, Penson PE, Vrablik M, et al; ACS EuroPath Centra \& South European Countries Project. Optimal use of lipid-lowering therapy after acute coronary syndromes: A Position Paper endorsed by the International Lipid Expert Panel (ILEP). Pharmacol Res 2021 Apr; 166: 105499. https://doi.org/10.1016/j.phrs.2021.105499 6. Márk L, Dani Gy, Ozsváth L, et al. Akut koronáriaszindróma miatt intervención átesett betegeink lipidcsökkentő kezelése és ajánlás a beavatkozás utáni ellenőrzésekre. Card Hung 2020; 50: 29-34. https://doi.org/10.26430/CHUNGARICA.2020.50.1.29

7. Ray KK, Molemans B, Schoonen WM, et al; DA VINCI study. EUWide Cross-Sectional Observational Study of Lipid-Modifying Therapy Use in Secondary and Primary Care: the DA VINCI study. Eur J Prev Cardiol 2020 Aug 28: zwaa047

https://doi.org/10.1093/eurjpc/zwaa047

8. Márk L, Reiber I, Bajnok L. Az ESC/EAS 2019. évi lipid ajánlása, az LDL-koleszterin célérték elérésének lehetőségei szívinfarktuson átesett igen nagy kockázatú betegekben. Card Hung 2020; 50: 298-302. https://doi.org/10.26430/CHUNGARICA.2020.50.4.298

9. Márk L, Jánosi A, Ferenci T, Andréka P. Szívinfarktust túlélt betegek lipidcsökkentő kezelése Magyarországon a Nemzeti Szívinfarktus Regiszter adatai alapján. Card Hung 2019; 49: 241-248. https://doi.org/10.26430/CHUNGARICA.2019.49.4.241

10. Volpe M, Patrono C. The increased mortality of STEMI patients without risk factors supports the need for evidence-based pharmacotherapy irrespective of perceived low risk. Eur Heart J 2021; 42 2329-2330. https://doi.org/10.1093/eurheartj/ehab268
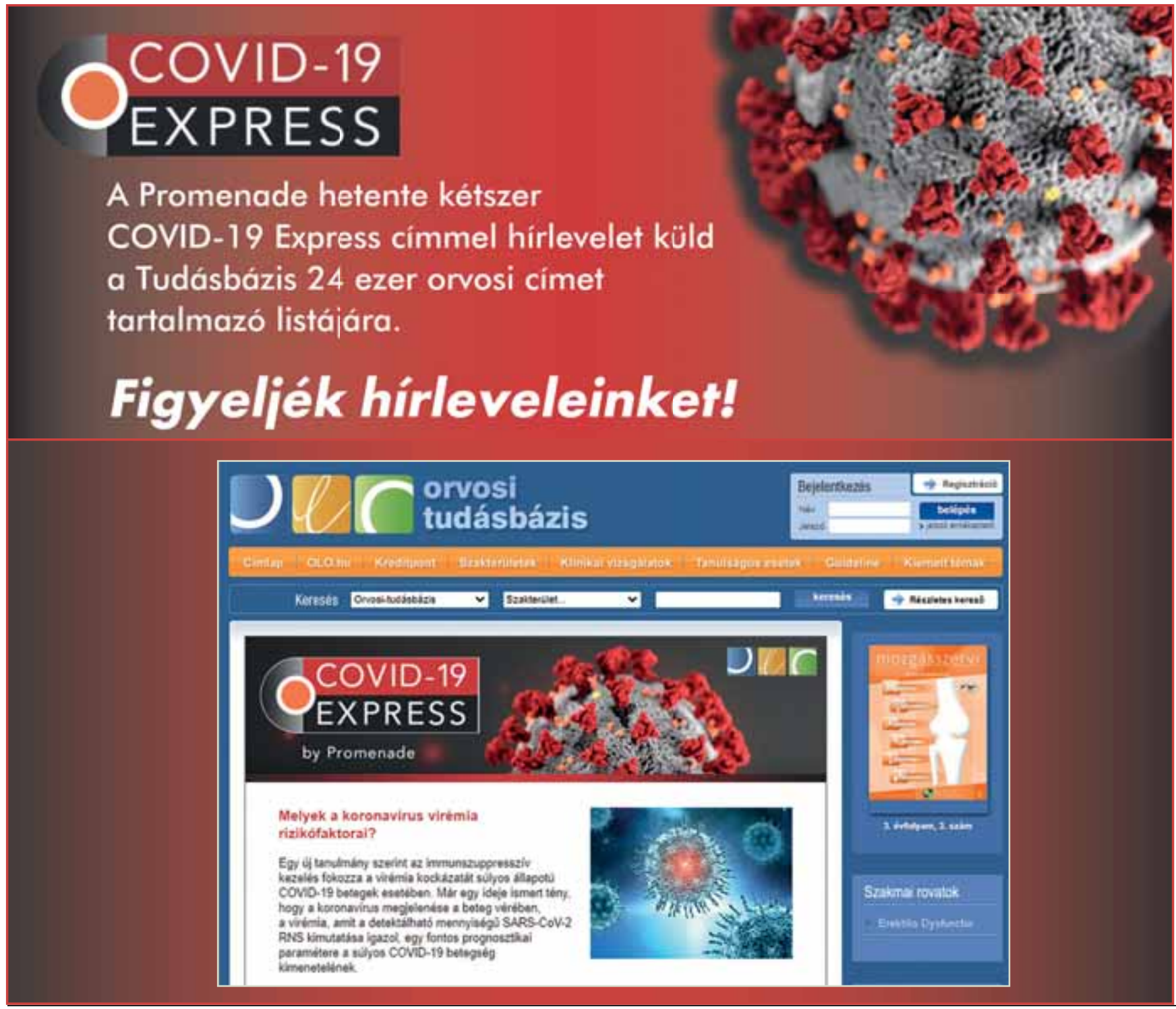